Article

\title{
Evaluation of Ingestive Behavior, Ruminal and Blood Parameters, Performance, and Thermography as a Phenotypic Divergence Markers of Residual Feed Intake in Rearing Dairy Heifers
}

\author{
Mayara Campos Lombardi ${ }^{1}$ (D), Hilton do Carmo Diniz Neto ${ }^{1}{ }^{(\mathbb{D}}$, Sandra Gesteira Coelho ${ }^{1}$, \\ Fernanda Samarini Machado ${ }^{2}$, Luiz Gustavo Ribeiro Pereira ${ }^{2} \mathbb{D}$, Thierry Ribeiro Tomich ${ }^{2} \mathbb{D}$ \\ and Mariana Magalhães Campos $2, *$ (D)
}

Citation: Lombardi, M.C.; Neto, H.d.C.D.; Coelho, S.G.; Machado, F.S.; Pereira, L.G.R.; Tomich, T.R.; Campos, M.M. Evaluation of Ingestive Behavior, Ruminal and Blood Parameters, Performance, and Thermography as a Phenotypic Divergence Markers of Residual Feed Intake in Rearing Dairy Heifers. Animals 2022, 12, 331. https:// doi.org/10.3390/ani12030331

Academic Editor: Changxi Li

Received: 7 December 2021

Accepted: 26 January 2022

Published: 29 January 2022

Publisher's Note: MDPI stays neutral with regard to jurisdictional claims in published maps and institutional affiliations.

Copyright: (C) 2022 by the authors. Licensee MDPI, Basel, Switzerland. This article is an open access article distributed under the terms and conditions of the Creative Commons Attribution (CC BY) license (https:/ / creativecommons.org/licenses/by/ $4.0 /)$.
1 Department of Animal Science, Veterinary School, Universidade Federal de Minas Gerais, Belo Horizonte 30161-970, MG, Brazil; mayaralombardi.vet@gmail.com (M.C.L.); hiltondinizneto@gmail.com (H.d.C.D.N.); sandragesteiracoelho@gmail.com (S.G.C.)

2 Brazilian Agricultural Research Corporation, Empresa Brasileira de Pesquisa Agropecuária-Embrapa Gado de Leite, Juiz de Fora 36038-330, MG, Brazil; fernanda.machado@embrapa.br (F.S.M.); luiz.gustavo@embrapa.br (L.G.R.P.); thierry.tomich@embrapa.br (T.R.T.)

* Correspondence: mariana.campos@embrapa.br

Simple Summary: The selection of highly efficient animals will support meeting the world's future demand for products and food of animal origin. Thus, the identification of efficient animals and an understanding of the mechanisms inherent to this efficiency is fundamental for the progress of breeding systems. In the present study, we identify highly efficient animals for residual feed intake in dairy heifers. This animal category is unexplored in relation to this index. We utilized the classical parameters evaluated in cattle of different ages to carry out the study on these animals.

\begin{abstract}
The objectives of this study were: (1) to identify and rank phenotypically divergent animals for residual feed intake (RFI) regarding their efficiency (high: HE or low: LE); (2) to evaluate their relationships with ingestive behavior, ruminal and blood parameters, performance, and infrared thermography; and (3) to determine if such measurements can be used as feed efficiency markers in rearing dairy heifers. Thirty-eight heifers, $143 \mathrm{~d} \pm 4$ (Mean $\pm \mathrm{SD}$ ) of age and $108.7 \mathrm{~kg} \pm 17.9$ of body weight were used. The animals were fed with a total mixed ration during the $91 \mathrm{~d}$ of the trial. A phenotypic divergence of DMI for RFI was observed between -0.358 and $0.337 \mathrm{~kg} / \mathrm{d}$ for HE and LE, respectively. Dry matter intake (DMI) was lower in the HE (2.5 kg DMI/d vs. $3.1 \mathrm{~kg} \mathrm{DMI} / \mathrm{d})$, as was the number of visits to the feed bin with consumption ( 59 vs. 71 ). Feed intake was the best predictor of said divergence. Water intake and number of visits to the feed bin were presented moderate correlations with RFI. The ruminal fermentation variables, blood metabolites, blood hormones (such as the other ingestive behavior variables), and infrared thermography were not able to accurately predict HE or LE animals.
\end{abstract}

Keywords: animal production; biological basis; feed efficiency; sustainability; water intake

\section{Introduction}

In the search for sustainability, animals that are more efficient at converting food into product are of unquestionable relevance [1,2]. The evaluation of feed efficiency can be obtained from measuring indexes such as feed conversion, average daily weight gain (ADG), residual body weight gain, residual feed intake (RFI), residual intake and body weight gain, or a combination of some of these indexes $[3,4]$. In this context, RFI appeared as a way to identify and classify animals in terms of their efficiency regarding consumption. 
Due to the fact that this index is not based on weight at adult age, it allows for the selection of more efficient animals, not necessarily with greater weight but with lower maintenance energy. In addition, the fact that animals evaluated for RFI demonstrate a maintenance of their superiority at different stages of life indicates the future sustainable and economic potential associated with the selection by this index [5].

The RFI corresponds to individual feed intake, obtained from the difference between the observed DMI and the estimated DMI for each animal [3]. For the calculation of RFI, an approximate trial period of $90 \mathrm{~d}$ [6] was necessary. In beef cattle, RFI was associated with other variables such as blood metabolites and hormone concentrations, ruminal fermentation ( $\mathrm{pH}$, volatile fatty acids production), and superficial body temperature by using infrared thermography, microbial profile, and ruminal enzymes [7-10]. Most recently, lactating cows and preweaning calves have been the subject of RFI studies [5,11]. Nevertheless, postweaning calves in dairy cattle were not studied. This animal category was very important in the systems, and it needs to be evaluated. In the future, these results could be associated with the RFI in adult cows.

Literature shows DMI to be a well-established parameter to define divergence in RFI since the classification is dependent on consumption [3]. However, daily and individual measurements are impractical and costly. On the other hand, parameters such as ingestive behavior, ruminal fermentation and blood metabolites, or hormones presented controversial results [8-11]. Thus, the search for effective and more accessible parameters as predictors of efficiency in RFI continues [6]. As this is an unexplored category in RFI, the present study evaluates dairy heifers using the classic parameters found in the literature for the RFI study of cattle at different stages of life.

Understanding the behavior and role of these variables and their association with the phenotypic classification for RFI in dairy heifer can help develop more practical ways of identifying them daily. The aim of this study was to identify and rank dairy cattle heifers for RFI, to evaluate their relationships with ingestive behavior, ruminal and blood parameters, performance, and infrared thermography in Gyr heifers and to determine if such measurements can be used as feed efficiency markers during heifer rearing.

\section{Materials and Methods}

The experiment was conducted with heifers born and bred at the EMBRAPA Dairy Cattle Experimental Farm, Coronel Pacheco, Minas Gerais, Brazil. The experiment was conducted during the spring; temperature $33.7{ }^{\circ} \mathrm{C} \pm 4.7$ and humidity: $73 \pm 9.56$. After the trial period, the animals remained in their herd according to EMBRAPA regulations and will be utilized in further research.

\subsection{Animals, Housing, and Management}

A total of 38 Gyr heifers (143 d $\pm 4 \mathrm{~d}$ of age and $108.7 \pm 17.9 \mathrm{~kg}$ of BW) was used. Immediately after birth, they were separated from their dams, moved to individual sandbedded tie-stalls, weighed, and had their umbilical cords immersed in $10 \%$ iodine solution. Colostrum $(10 \%$ of BW at birth; $>50 \mathrm{~g}$ of $\mathrm{IgG} / \mathrm{L})$ was provided within $6 \mathrm{~h}$ after birth. During preweaning, calves received water and a starter (Soymax Rumen Pré-Inicial Floc-Total Alimentos, Três Corações, Minas Gerais, Brazil) at ease, and milk (42\% of metabolic birth body weight). From $3 \mathrm{~d}$ of age, $8 \%$ chopped hay (Tyfton 85 ) was included. Weaning was at $87 \mathrm{~d}$ of age, and the animals stayed in their housing up to $101 \mathrm{~d}$ of age.

At $101 \mathrm{~d}$ of age, the heifers were transferred to a grass-covered paddock (Cynodon dactylon; $1350 \mathrm{~m}^{2}$ ) with a concrete area near the troughs, where they stayed during $28 \mathrm{~d}$ of adaptation and socialization. During the first seven days, their diet was $75 \%$ of the preweaning starter plus $25 \%$ of total mixed ration (TMR; $7 \%$ corn silage and $25 \%$ concentrate) (Table 1). In the second week, they were fed $50 \%$ of the preweaning starter plus $50 \%$ of TMR. In the third week, their diet consisted of $25 \%$ of the preweaning starter plus $75 \%$ of TMR, and in the last week $100 \%$ of TMR was fed to the heifers. Feed was supplied at will, ensuring a minimum $10 \%$ of leftovers. 
Table 1. Nutritional composition (dry matter basis, \% unless otherwise noted) of concentrate, corn silage and total mixed ration offered to heifers during trial period.

\begin{tabular}{cccc}
\hline Nutritional Composition & Concentrate $^{\mathbf{1}}$ & Corn Silage & TMR $^{\mathbf{2}}$ \\
\hline $\mathrm{DM}^{3}$ & 88.45 & 35.10 & 48.40 \\
$\mathrm{TDN}^{4}$ & 85.10 & 75.80 & 77.20 \\
$\mathrm{CP}^{5}$ & 33.31 & 8.10 & 14.41 \\
$\mathrm{EE}^{6}$ & 2.96 & 4.00 & 3.76 \\
$\mathrm{ASH}^{7}$ & 11.87 & 6.10 & 7.54 \\
$\mathrm{NDF}^{8}$ & 11.69 & 42.90 & 35.12 \\
$\mathrm{ME}^{9}(\mathrm{kcal} / \mathrm{kg})$ & 3591.00 & 2240.00 & 2577.00 \\
$\mathrm{GE}^{10}(\mathrm{kcal} / \mathrm{kg})$ & 4205.84 & 4510.50 & 4433.57 \\
\hline
\end{tabular}

${ }^{1}$ Concentrate composition: $64 \%$ soybean meal, $30 \%$ ground corn and $6 \%$ mineral core; ${ }^{2}$ TMR = total mixed ration ${ }^{3} \mathrm{DM}=$ dry matter; ${ }^{4} \mathrm{TDN}=$ total digestible nutrients; ${ }^{5} \mathrm{CP}=$ crude protein; ${ }^{6} \mathrm{EE}=$ ethereal extract; ${ }^{7} \mathrm{ASH}=$ ashes;

${ }^{8} \mathrm{NDF}=$ neutral detergent fiber; ${ }^{9} \mathrm{ME}=$ metabolizable energy; ${ }^{10} \mathrm{GE}=$ gross energy.

Samples $(0.5 \mathrm{~kg})$ of corn silage and concentrate were collected three times a week then homogenized and packaged (at $-20^{\circ} \mathrm{C}$ ). Feed samples were dried in a forced-ventilation oven at $55^{\circ} \mathrm{C}$ for $72 \mathrm{~h}$ and then ground to $1 \mathrm{~mm}$ particle size in a Wiley Mill (model 3, Arthur H. Thomas Co., Philadelphia, PA, USA). Dry matter, crude protein, ethereal extract, and ashes were determined according to AOAC [12], and neutral detergent fiber was determined by the method of Van Soest [13]. Total digestible nutrients and metabolizable energy were calculated according to NRC [14]. Gross energy was determined using an adiabatic bomb calorimeter (IKA-C5000, IKA1 Works, Staufen, Germany).

\subsection{Feed Intake, Water Intake, Body Weighing, Average Daily Gain, and Ingestive Behavior}

The heifers were submitted to a trial period of $91 \mathrm{~d}$ in which they were fed with TMR twice a day at 08:30 and 15:30 h, and water was supplied at ease. The paddock was equipped with nine electronic feed bins (AF1000 JUNIOR Intergado Ltd., Contagem, Minas Gerais, Brazil) with a capacity of $55 \mathrm{~kg}$ and accuracy of $\pm 0.025 \mathrm{~kg}$ and three electronic water bins (WD1000 Intergado Ltd., Contagem, Minas Gerais, Brazil) with a capacity of $40 \mathrm{~kg}$ of water and accuracy of $\pm 0.025 \mathrm{~kg}$. A body-weighing station (WD 1000 Intergado Ltd., Contagem, Minas Gerais, Brazil) with a capacity of $400 \mathrm{~kg}$ and accuracy of $\pm 0.100 \mathrm{~kg}$ was coupled with each water bin so that to have access, the animals were kept at the weighing station. This technology has been tested and validated [15]. For the purposes of identification, each animal received an earring with an electronic transponder with an individual coding (FDX-ISSO 11784/11785; Allflex, Joinville, Brazil) before the trial period.

Water and feed consumption were measured daily and individually as the difference in weight between the bin content at the beginning and end of the visit. Collection data were processed and stored by software from Intergado Ltd. Out of the total data collected in the $91 \mathrm{~d}$ of trial (intake, water intake and weighing), $16.5 \%$ were excluded due to occurrences unrelated to the equipment, such as days for maintenance of the paddock, heavy rain, and poor positioning of the animals on the body-weighing platform. Then $76 \mathrm{~d}$ were considered for consumption analysis and $90 \mathrm{~d}$ for weighing analysis, with $420 \pm 87$ weighing data being used for each animal. ADG was automatically calculated by software from Intergado Ltd. After the removal of the outliers, BW data were submitted to linear regression models, in which ADG was obtained from the first derivation of the selected model and calculated from the differences between the daily body weighing results.

To evaluate ingestive behavior, the following data provided by software from Intergado Ltd. were used: total time at the bin (TTB), consumption time at the bin (CTB), number of visits to the feed bin with consumption (NVB), total time at the water bin (TTW), and number of visits at the water bin (NVW). Values of TTB lesser than $60 \mathrm{~min} / \mathrm{d}$ and greater than $600 \mathrm{~min} / \mathrm{d}$ were excluded from the analyses after pre-evaluation of the data since they were not within the normal values considering the average of time of all animals during the evaluation period. Values of TTW greater than $99 \mathrm{~min} / \mathrm{d}$ were excluded for the same reason. 


\subsection{Residual Feed Intake}

The RFI is the difference between the standardized daily DMI and the expected DMI. Therefore, the expected DMI was calculated using that is predicted based on animal growth and metabolic body as observed in the preestablished linear regression model [9]:

$$
Y j=\beta 0+\beta 1\left(B W^{* *} 0.75 j\right)+\beta 2(A D G j)+e j
$$

where:

Yj: standardized DMI of heifer $\mathrm{j}$;

$\beta 0$ : is the regression intercept;

$\beta 1$ : is the regression coefficient on $B W^{* *} 0.75$ to animal $j$,

$\beta 2$ : is the regression coefficient on ADG to animal $j$,

ej: is the associated error to animal $\mathrm{j}$.

The classification of HE or LE was made according to the standard deviation (SD) around the mean value found for all animals (38): HE-RFI: $<0.5$ SD under the mean; $n=13$, and LW-RFI: $>0.5$ SD above the mean; $n=14$.

\subsection{Rumen Variables and Analyses}

A total of $100 \mathrm{~mL}$ of ruminal liquid was collected from each animal at 30, 60, and $90 \mathrm{~d}$ of trial, $3 \mathrm{~h}$ after the first feed, with the support of a flexible orogastric tube. The samples were sifted and filtered in double gauze. The $\mathrm{pH}$ was measured immediately with the aid of a portable potentiometer (DM-2-Digimed, São Paulo, Brazil). Samples were divided into two recipients: the first with $10 \mathrm{~mL}$ of ruminal liquid plus $2 \mathrm{~mL}$ of metaphosphoric acid (concentration 20\%) for volatile fatty acid (VFA; acetate, propionate, and butyrate) concentration analysis; and the second with $10 \mathrm{~mL}$ of ruminal liquid plus $1 \mathrm{~mL}$ of sulfuric acid (50\%) for analysis of ruminal ammoniacal nitrogen concentration.

Samples were centrifuged at $1800 \times g$ for $10 \mathrm{~min}$ at room temperature $\left(22-25^{\circ} \mathrm{C}\right)$ for measurement of VFA concentration using high performance liquid chromatography (Waters Alliance e2695 Chromatograph, Waters Technologies Brazil LTDA, Barueri, Brazil) with a C18 ODS 80A reverse-phase column separation system $(150 \times 4.6 \mathrm{~mm} \times 5 \mu \mathrm{m})$. The conditions of analysis were an isocratic mobile phase consisting of $100 \%$ aqueous phosphoric acid solution, $\mathrm{pH} 2.35-2.55$, oven temperature of $40 \pm 5{ }^{\circ} \mathrm{C}$, sample injection volume of $10 \mu \mathrm{L}$, run time of $20 \mathrm{~min}$, and a detector with a wavelength of $210 \mathrm{~nm}$. The ruminal ammoniacal nitrogen concentration was quantified after the distillation of Kjeldahl according to the INCT-CA N007/1 method [16] with boric acid solution (40 g/L), potassium hydroxide solution $(132 \mathrm{~g} / \mathrm{L})$, and hydrochloric acid $(0.49 \mathrm{~g} / \mathrm{L})$. After quantification, the adjustment required to use this method was performed according to INCT-CA N007/1 method.

\subsection{Blood Metabolites and Hormones}

Blood samples $(30 \mathrm{~mL})$ were collected from all the animals to determine metabolites and hormones at 30,60, and $90 \mathrm{~d}, 3 \mathrm{~h}$ after the first feed of the day. The sample collections were carried out with local antisepsis (70\% alcohol) by venous puncture of the jugular. Four siliconized vacuum tubes (Becton, Dickinson and Company, Franklin Lakes, MJ, USA) were collected: two $(5 \mathrm{~mL})$ containing sodium fluoride for plasma extraction, and two $(10 \mathrm{~mL})$ without content for serum extraction. The samples were immediately centrifuged at $800 \mathrm{RPM}$ for $10 \mathrm{~min}$ and stored in aliquots of $1.5 \mathrm{~mL}$ at $-20{ }^{\circ} \mathrm{C}$.

Plasma was used for glucose dosing by using an EON microplate spectrophotometer (Biotek Instruments Inc., Vermont, VT, USA) via the enzymatic method: glucose oxidase (Kovalent do Brasil Ltd., Rio de Janeiro, Brazil). Serum was used for insulin and insulin-like growth factor 1 (IGF-1) dosing. Analysis was carried out in the Immulite $2000^{\circledR}$ (Siemens Healthineers, Brazil). The reagent Insulina 200T (IMM2) L2KIN2 ${ }^{\circledR}$ and control Biorad Liphocheck Control Trilevel Imuno ${ }^{\circledR}$ were used for insulin, and the reagent IGF-1 200 Tests $(\mathrm{IMM} 2)^{\circledR}$ and control IGF1/IGFBP 3 (IMM) ${ }^{\circledR}$ were used for IGF-1 (Prohosp Distribuidora de Medicamentos LTDA, Belo Horizonte, Minas Gerais, Brazil). 


\subsection{Infrared Thermography}

Thermographic evaluations were carried out at 30,60, and $90 \mathrm{~d}$. Thermographic images were obtained with the support of the portable device, FLIR T420 ${ }^{\circledR}$ (FLIR Systems, Inc., Wilsonville, OR, USA). The distance from the thermograph to the photographed anatomical area was standardized at $1 \mathrm{~m}$, and the device settings were adjusted to $20{ }^{\circ} \mathrm{C}$ reflectance temperature and 0.98 emissivity [11]. The archives were processed and interpreted by software FLIR Tools 5.6 ${ }^{\circledR}$ (FLIR Systems, Wilsonville, OR, USA) displayed on the iron palette. Measuring tools took the form of rectangles with different dimensions used in various anatomical areas: $40 \mathrm{~mm} \times 30 \mathrm{~mm}$ for cheek, $150 \mathrm{~mm} \times 120 \mathrm{~mm}$ for right rib, $10 \mathrm{~mm} \times 10 \mathrm{~mm}$ for muzzle, $80 \mathrm{~mm} \times 120 \mathrm{~mm}$ for left flank, $10 \mathrm{~mm} \times 20 \mathrm{~mm}$ for front, $15 \mathrm{~mm} \times 25 \mathrm{~mm}$ front limb, and $15 \mathrm{~mm} \times 25 \mathrm{~mm}$ for hind limb. The evaluation was carried out using the maximum temperature of each area.

\subsection{Statistical Analysis}

The software SAS (SAS Institute Inc., Cary, NC, USA, version 9.4) was used. To evaluate the effects of efficiency in the groups, the MIXED procedure was used according to the model:

$$
Y \_i j k=\beta \_0+\beta \_1 \mathrm{~A} \_i j+\beta \_2 \mathrm{~B} \_\mathrm{ij}+\mathrm{G} \_\mathrm{i}+\mathrm{M} \_\mathrm{k}+[\mathrm{GM}] \_\mathrm{ik}+\delta \_i j+\varepsilon \_i j k
$$

where:

Y_ijk: dependent variable;

$\beta \_0$ : intercept;

$\beta \_1$ A_ij: regression coefficient for the covariate initial BW;

$\beta \_2$ B_ij: regression coefficient for the covariate total serum protein;

G_i: fixed effect of efficiency group;

M_k: fixed effect of repeated measure (day or week);

[GM]_ik: fixed effect of interaction between group and repeated measure;

$\delta \_$ij: random error between animals within treatment;

$\varepsilon \_i j k$ : random error between measurements among animals.

The mean, standard deviation, normality, and homoscedasticity were analyzed using the PROC-UNIVARIATE procedure. Abnormal variables were transformed according to their characteristics. Initial BW and total serum protein were tested as covariates and included in the model only if significant $(p<0.05)$. Initial body weight, final body weight, and ADG were analyzed using the PROC GLM. The remaining data were analyzed using repeated measures over time (PROC MIXED). HE-RFI or LE-RFI and repeated measures over time (day or week) were included in the model as fixed effects.

The PROC CORR procedure was used for the evaluation of the correlation between the variables. The correlations were classified as low $(r<0.30)$, moderate $(0.30>r>0.70)$, or strong $(\mathrm{r}>0.70)$. The $p$-value was considered significant when $p<0.05$.

\section{Results and Discussion}

\subsection{Residual Feed Intake, Feed and Water Intake, and Performance}

A phenotypic divergence of DMI for RFI was observed between -0.358 and $0.337 \mathrm{~kg} / \mathrm{d}$ for HE and LE, respectively ( $p<0.0001$ ) (Table 2$)$. This variation represented a reduction of approximately $63.25 \mathrm{~kg}$ of DM for each animal during the trial period. The minimum and maximum values of RFI were -0.868 (HE) and $0.881 \mathrm{~kg} / \mathrm{d}(\mathrm{LE})$, respectively, representing a difference of $1.75 \mathrm{~kg} / \mathrm{d}$ of DM between the most or least efficient animals. The total DMI was $19.3 \%$ less in the HE animals $(p<0.0001)$. The difference was greater than the $15.9 \%, 13.0 \%$, and $8.9 \%$ differences reported in other studies $[9,11,17]$. The first study was conducted with a Holstein $\times$ Limousin crossbreed ( $247 \mathrm{~d}$ of age) while the second and third evaluated Holstein $\times$ Gyr, and Gyr from birth to weaning. The major variation found in animals from $247 \mathrm{~d}$ and in the present study may be due to the life phase in which the evaluations were carried out. After weaning, the animals presented more advanced age 
and greater BW and were no longer subjected to a liquid diet, which may have allowed a major expression of variation in individual DMI. No difference was found in ADG between HE-RFI and LE-RFI in the present study. These results are in accordance with those reported by Basarab et al. [18] and McDonnel et al. [19].

Table 2. Means of the indexes, intakes, and performances evaluated for HE and LE in residual feed intake (RFI); standard error of the mean (SEM) and group interaction (high efficiency: HE or low efficiency: LE) in dairy heifers phenotypically classified for RFI.

\begin{tabular}{|c|c|c|c|c|}
\hline \multirow{2}{*}{ Item } & \multicolumn{2}{|c|}{ RFI ${ }^{1}$} & \multirow{2}{*}{ SEM $^{4}$} & \multirow{2}{*}{$p$-Value } \\
\hline & $\mathrm{HE}^{2}$ & $\mathrm{LE}^{3}$ & & \\
\hline $\begin{array}{l}\mathrm{RFI}(\mathrm{kg} / \mathrm{d}) \\
\text { Intake }\end{array}$ & -0.358 & 0.337 & 0.06 & $<0.0001$ \\
\hline Water (L/d) & 7.2 & 7.0 & 0.50 & 0.024 \\
\hline $\mathrm{DMI}^{5}(\mathrm{~kg} / \mathrm{d})$ & 2.5 & 3.1 & 0.17 & $<0.0001$ \\
\hline $\begin{array}{l}\text { Water: DMI ratio } \\
\text { Performance }\end{array}$ & 3.5 & 2.7 & 0.30 & $<0.0001$ \\
\hline $\operatorname{ADG}^{6}(\mathrm{~kg} / \mathrm{d})$ & 0.305 & 0.237 & 0.35 & 0.3662 \\
\hline $\begin{array}{l}\text { Initial weight } \\
\text { body }(\mathrm{kg})\end{array}$ & 106.3 & 107.6 & 1.88 & 0.8214 \\
\hline $\begin{array}{l}\text { Final weight } \\
\text { body }(\mathrm{kg})\end{array}$ & 133.7 & 128.9 & 4.22 & 0.4682 \\
\hline
\end{tabular}

${ }^{1} \mathrm{RFI}=$ residual feed intake $;{ }^{2} \mathrm{HE}=$ high efficiency (RFI smaller than 0.5 SD below average) $;{ }^{3} \mathrm{LE}=$ low efficiency (RFI greater than $0.5 \mathrm{SD}$ above average); ${ }^{4} \mathrm{SEM}=$ standard error of the mean; ${ }^{5} \mathrm{DMI}=$ dry matter intake; ${ }^{6} \mathrm{ADG}=$ average daily gain.

To our knowledge, the present study is the first study to assess water consumption in phenotypically divergent dairy heifers for RFI. Water intake ranged between HE-RFI (7.2 L) and LE-RFI (7.0 L; $p=0.024$ ) (Table 2). High-efficiency animals consumed proportionally more water in relation to their BW. Water intake is not a frequently measured parameter in studies and routines on farms, probably due to the difficulty of measuring. However, water is essential for the physiological process and is related to DMI, development, and ADG [20,21]. Increased water intake beyond that needed for organic functions does not reflect a higher DMI; nevertheless, when water intake is lower than the minimum required, it is followed by a reduction in DMI [22]. The ratio between water intake and DMI was 3.5 vs. 2.7 for HE-RFI and LE-RFI, respectively $(p<0.0001)$. The increase of water requirements does not keep up with body growth rate and body weight gain [23], as observed in our study, leading us to assume that greater water intake by $\mathrm{HE}$ could be related to some energetic metabolic pathway [21]. We believe that future studies on the biological bases involved in the phenotypic differences related to RFI should consider the assessment of water consumption, in order to elucidate the reasons for the higher water intake in HE animals.

\subsection{Ingestive Behavior}

Daily activity by animals is believed to contribute approximately $5 \%$ to the variation in RFI [7]. The values of total time at the bin and CTB were not different, as indicated in an earlier work [18]. However, NVB had less HE-RFI than LE-RFI (59 vs. 71; $p<0.001$ ) (Table 3). Although moderate, except for the NVB, the other variables related to ingestive behavior showed no significance when correlated with RFI [23] (Table 4).

HE-RFI animals can reach a difference of up to $22 \%$ in NVB $[9,23]$. In the present study, the difference was $16.9 \%$. These findings show that the HE animals had less consumption time and consequently less intake in fewer visits and, as a result, fed more slowly and moved less often to go to the trough. Similar behavior was observed in Holstein heifers ( 5 to 9 months of age) [24]. Although our results are not in full agreement with previous studies, it is plausible to suppose, as suggested by these authors, that the HE groups possibly 
employed less energy in food events, so the energy saved could be used in other metabolic and physiological functions.

Table 3. Ingestive behavior, ruminal fermentation, blood parameters and infrared thermography in HE and LE dairy heifers phenotypically classified for RFI.

\begin{tabular}{|c|c|c|c|c|}
\hline \multirow{2}{*}{ Item } & \multicolumn{2}{|c|}{ RFI $^{1}$} & \multirow{2}{*}{ SEM $^{4}$} & \multirow{2}{*}{$p$-Value } \\
\hline & $\mathrm{HE}^{2}$ & $\mathrm{LE}^{3}$ & & \\
\hline \multicolumn{5}{|l|}{ Ingestive behavior } \\
\hline $\mathrm{TTB}^{5}(\mathrm{~min})$ & 152 & 152 & 8.27 & 0.36 \\
\hline $\mathrm{CTB}^{6}(\mathrm{~min})$ & 126 & 126 & 7.90 & 0.14 \\
\hline $\mathrm{NVB}^{7}$ (occurrence) & 59 & 71 & 0.80 & $<0.0001$ \\
\hline $\mathrm{TTW}^{8}(\mathrm{~min})$ & 16 & 11 & 0.06 & $<0.0001$ \\
\hline $\mathrm{NVW}^{9}$ (occurrence) & 5.9 & 5.50 & 0.34 & $<0.0001$ \\
\hline \multicolumn{5}{|l|}{ Ruminal parameters } \\
\hline $\mathrm{pH}$ & 6.80 & 6.90 & 0.16 & 0.74 \\
\hline $\mathrm{N}-\mathrm{NH}_{3}{ }^{10}(\mathrm{mg} / \mathrm{dL})$ & 13.70 & 14.50 & 1.17 & 0.25 \\
\hline Acetate $(\mu \mathrm{mol} / \mathrm{mL})$ & 41.60 & 43.10 & 3.34 & 0.45 \\
\hline Butyrate $(\mu \mathrm{mol} / \mathrm{mL})$ & 8.70 & 8.80 & 0.86 & 0.72 \\
\hline Propionate $(\mu \mathrm{mol} / \mathrm{mL})$ & 7.90 & 7.80 & 0.66 & 0.91 \\
\hline Acetate:propionate & 5.30 & 5.20 & 0.41 & 0.60 \\
\hline Total VFA $(\mu \mathrm{mol} / \mathrm{mL})$ & 58.80 & 60.40 & 4.45 & 0.53 \\
\hline \multicolumn{5}{|l|}{ Blood parameters } \\
\hline Glucose (mg/dL) & 78.80 & 80.20 & 2.98 & 0.42 \\
\hline Insulin (uIU/mL) & 11.10 & 11.30 & 2.37 & 0.89 \\
\hline IGF-1 ${ }^{11}(\mathrm{ng} / \mathrm{mL})$ & 82.90 & 89.90 & 18.31 & 0.47 \\
\hline Ratio glucose:insulin & 9.20 & 9.50 & 1.83 & 0.72 \\
\hline \multicolumn{5}{|l|}{ Infrared termography $\left({ }^{\circ} \mathrm{C}\right)$} \\
\hline Cheek & 35.30 & 34.70 & 0.45 & 0.37 \\
\hline Right rib & 35.70 & 35.20 & 0.68 & 0.71 \\
\hline Left flank & 36.60 & 34.80 & 0.82 & 0.08 \\
\hline Front & 33.20 & 31.40 & 1.30 & 0.24 \\
\hline Muzzle & 31.90 & 29.20 & 1.27 & 0.26 \\
\hline Front limb & 35.30 & 33.00 & 1.29 & 0.34 \\
\hline Hind limb & 30.80 & 29.70 & 1.28 & 0.50 \\
\hline
\end{tabular}

${ }^{1} \mathrm{RFI}=$ residual feed intake; ${ }^{2} \mathrm{HE}=$ high efficiency; ${ }^{3} \mathrm{LE}=$ low efficiency; ${ }^{4} \mathrm{SEM}=$ standard error of mean ${ }^{5} \mathrm{TTB}=$ total time at the bin; ${ }^{6} \mathrm{CTB}=$ consumption time at the bin; ${ }^{7} \mathrm{NVB}=$ number of visits to the feed bin with consumption; ${ }^{8} \mathrm{TTW}=$ total time at the water bin; ${ }^{9} \mathrm{NVW}=$ number of visits to the water bin; ${ }^{10} \mathrm{~N}-\mathrm{NH}_{3}=$ ammonia nitrogen content; ${ }^{11}$ IGF-1 = insuline-like growth factor 1 .

Regarding water intake behavior, TTW (16 vs. $11 \mathrm{~min}$ ) and NVW (5.9 vs. 5.5) differed between groups $(p<0.0001)$, being higher for HE-RFI animals (Table 3$)$. In the present study, the HE animals consumed less food that was associated with higher TTW and water consumption, suggesting that the water intake is related to physiological functions in other tissues that contributed to the phenotypic divergence in RFI.

\subsection{Ruminal Fermentation}

We hypothesized that some changes could be observed between the groups, since part of the variation in feed efficiency is related to digestion and energy metabolism [25], but this was not confirmed by the results, because no differences were observed in any ruminal fermentation variables (Table 3). Guan et al. [26] observed a higher concentration of butyrate in HE-RFI animals and a higher concentration of total VFA and acetate in LE-RFI animals $(p=0.059$ and $p=0.074)$. Those authors suggested that there was increased microbial activity in HE-RFI animals. However, as in the present study, no variation in the ruminal fermentation profile was found by other authors [2,27]. Nevertheless, according to Trevizan et al. [2], other factors may have greater relevance to the efficiency of these animals than the ruminal fermentation profile. In this sense, Elolimy et al. [5] found different profiles of microorganisms and different metabolic potentials associated with 
metabolites of energetic pathways between low and high-efficiency Holstein heifers at birth and during preweaning.

Table 4. Phenotypic correlation of dry matter intake (DMI), average daily gain (ADG), and RFI with the performance indexes and evaluated variables in dairy heifers phenotypically classified for RFI.

\begin{tabular}{|c|c|c|c|}
\hline Item & DMI $^{1}$ & $\mathrm{ADG}^{2}$ & $\mathrm{RFI}^{3}$ \\
\hline \multicolumn{4}{|l|}{ Intake/Performance } \\
\hline RFI & - & - & - \\
\hline DMI & - & $0.60^{* * *}$ & $0.78^{* * *}$ \\
\hline Water intake & - & $0.50^{* *}$ & - \\
\hline ADG & $0.60^{* * *}$ & - & - \\
\hline Initial body weight & $0.37 *$ & $0.57^{* *}$ & - \\
\hline Final body weight & $0.56^{* *}$ & $0.91^{* * * *}$ & - \\
\hline \multicolumn{4}{|l|}{ Ingestive behaviour } \\
\hline TTB $^{4}$ & - & $0.06^{* *}$ & - \\
\hline $\mathrm{CTB}^{5}$ & - & $0.06^{* *}$ & - \\
\hline $\mathrm{NVB}^{6}$ & $0.43 *$ & - & 0.38 * \\
\hline TTW $^{7}$ & $0.18^{* * *}$ & $0.18^{* * *}$ & $-0.13^{* * *}$ \\
\hline NVW $^{8}$ & $0.18^{* * *}$ & $0.18^{* * *}$ & 0.04 * \\
\hline \multicolumn{4}{|l|}{ Blood variables } \\
\hline Glucose & $0.33^{* *}$ & $0.35^{* *}$ & - \\
\hline IGF-1 9 & $0.30 * *$ & $0.31^{* *}$ & - \\
\hline
\end{tabular}

${ }^{1} \mathrm{DMI}=$ Dry matter intake; ${ }^{2} \mathrm{ADG}=$ Average daily gain; ${ }^{3} \mathrm{RFI}=$ Residual feed intake; ${ }^{4} \mathrm{TTB}=$ Total time at the bin ${ }^{5} \mathrm{CTB}=$ Consumption time at the bin; ${ }^{6} \mathrm{NVB}=$ Number of visits to the feed bin with consumption; ${ }^{7} \mathrm{TTW}=\mathrm{Total}$ time at the water bin; ${ }^{8} \mathrm{NVW}=\mathrm{Number}$ of visits to the water bin; ${ }^{9}$ IGF-1 = Insuline-like growth factor $1 ;{ }^{*} p<0.05$; ** $p<0.01 ;{ }^{* * *} p<0.0001$ and (-) no significance.

For rumen functioning, factors such as food, water, and microorganisms are necessary, and the variation in their quantity and quality may interfere with ruminal parameters as well as with their development [22]. However, the variation in the concentration of VFA is most evident in the preweaning phase, when intense changes in rumen development occur. Heifers in this study received a solid diet of high granulometry and hay while still in the preweaning phase, which may have had a positive effect on most of the rumen development in this phase of life, causing the animals to reach postweaning with similar ruminal developed.

A study of dairy cows found that more efficient animals presented lower amylase, cellulase, and protease activity, which was attributed to the DMI decreased [28]. The authors believe that the lower DMI allowed animals with HE to have a longer time for digestion, requiring less food to support their maintenance. Together with the microbial profile, these results show that, because they are closely related to DMI, the most varied conditions of the rumen environment can be associated with the RFI phenotype.

\subsection{Blood Metabolites and Hormones}

No differences were observed in glucose, insulin, and IGF-1 concentrations, and the glucose:insulin ratio between HE and LE groups for RFI (Table 3), was corroborated in research that found no difference in glucose concentration between HE-RFI and LE-RFI [29]. However, a moderate correlation was observed between glucose and DMI $(0.33 ; p=0.0017)$ and between glucose and ADG $(0.35 ; p=0.0009)$ (Table 4$)$. These findings were similar to those of other works that reported the significant effects of glucose concentrations on DMI and ADG $[9,30]$. As suggested in those works, this effect was likely the result of the physiological increase in DMI as the age of the animal advances. Diet type and composition may affect the way IGF-1 and RFI relate to each other and may generate positive correlations between IGF-1 and RFI in high roughage diets as well as negative correlations when using highly concentrated diets [31]. In our study, as with glucose, IGF-1 had a moderate correlation with DMI $(0.30 ; p=0.0066)$ and ADG $(0.31 ; p=0.0035)$. However, a correlation between IGF-1 and RFI was not observed, contrary to in the results of another work that 
reported a moderate correlation between both [32]. DMI elevates the insulin concentration in response to nutrient absorption by the gastrointestinal tract. In the present study, a divergence in insulin concentration was expected to be found that would demonstrate the possible superiority of metabolic efficiency of HE-RFI. Nevertheless, this hypothesis was not confirmed since unlike glucose and IGF-1, the insulin and glucose:insulin ratio did not correlate with DMI and ADG. We do not recommend their use when studying phenotypic divergence in RFI for heifers.

\subsection{Infrared Thermography}

No differences were found in infrared thermography between HE-RFI and LE-RFI. However, although there was no difference between the groups considering the entire evaluation period, a difference was detected in only the infrared thermography at $30 \mathrm{~d}$. The maximum left flank temperature at $30 \mathrm{~d}$ was $36.6^{\circ} \mathrm{C}$ for HE-RFI and $34.8^{\circ} \mathrm{C}$ for LE-RFI $(p=0.0292)$ and the muzzle was $31.9^{\circ} \mathrm{C}$ for HE-RFI and $29.1{ }^{\circ} \mathrm{C}$ for LE-RFI $(p=0.0218)$ (Table 3). In previous works on dairy cattle, authors reported greater temperatures on the udder in LE-RFI adult animals [33]. The researchers suggested that HE-RFI animals would have greater energy efficiency and thus lower surface temperatures. In contrast, other works reported higher surface temperatures in HE-RFI animals in beef cattle [10,34]. Those authors suggest that greater feed-efficient animals had higher surface temperatures which were related to their metabolic efficiency [35], which led to greater heat dissipation by radiation. Although differences were observed at $30 \mathrm{~d}$ for the HE and LE groups, the present study does not support the idea that infrared thermography would be a potential tool for finding RFI phenotypic divergence in heifers due to the weaker correlation between the thermographic variables and the classifications of these indexes.

\section{Conclusions}

Phenotypic divergence in RFI was observed in the dairy heifers studied. Feed intake was the best predictor of said divergence. Water intake and the number of visits to the feed bin presented moderate correlations with RFI. Ruminal and blood parameters, ingestive behavior, and infrared thermography evaluated in this work were not good predictors of phenotypic divergence for RFI in dairy heifers. Future studies should be conducted to explain the relationship of these variables to the biological bases that lead to the differences in feed efficiency in animals.

Author Contributions: M.M.C., F.S.M., L.G.R.P. and T.R.T. conceived and designed the study; M.C.L. and H.d.C.D.N. performed the experiments; H.d.C.D.N. and M.C.L. analyzed the data; M.C.L., H.d.C.D.N. and S.G.C. wrote the manuscript. All authors have read and agreed to the published version of the manuscript.

Funding: The funding of support received during this specific study came from EMBRAPA, http: / / www.embrapa.br/ (accessed on 10 July 2021), project title: "Influence of genetic, productive, metabolic, behavioral, health and economic characteristics on feed efficiency in Gyr heifers in the rearing phase in feedlot and grazing", number: 0.16.04.005.00.00 (MMC), and the scholarships came from the Conselho Nacional de Desenvolvimento Científico e Tecnológico, http:/ / cnpq.br (CNPq) (accessed on 10 July 2021) and Instituto Nacional de Ciência e Tecnologia-Ciência Animal (INCT-CA), http:/ /inct.cnpq.br/web/inct-ca (accessed on 10 July 2021). The funders had no role in the study design, data collection and analysis, decision to publish, or preparation of the manuscript.

Institutional Review Board Statement: This study was conducted according to the guidelines of the Animal Use Ethics Committee and approved by the Ethics Committee of Embrapa Gado de Leite (protocol code 1201110717).

Informed Consent Statement: Not applicable.

Data Availability Statement: The data that support the findings and which are presented in this study are available on reasonable request from the corresponding author, Mariana Magalhães Campos, mariana.campos@embrapa.br. The data are not publicly available as not all data of the study has been published yet. 
Acknowledgments: We thank the EMBRAPA for their financial support, the farm personnel and students who assisted with this project, and the EMBRAPA and Canoa farm that allowed us to use the animals in this study.

Conflicts of Interest: The authors declare no conflict of interest. The funders played no role in the design of the study; collection, analysis, and interpretation of data; or preparation or approval of the manuscript.

\section{References}

1. Britt, J.H.; Cushman, R.A.; Dechow, C.D.; Dobson, H.; Humblot, P.; Hutjens, M.F.; Jones, G.A.; Ruegg, P.S.; Sheldon, I.M.; Stevenson, J.S. Invited review: Learning from the future-A vision for dairy farms and cows in 2067. J. Dairy Sci. 2018, 101, 3722-3741. [CrossRef]

2. Trevizan, N.; Canesin, R.C.; Branco, R.H.; Batalha, C.D.A.; Cyrillo, J.N.S.G.; Bonilha, S.F.M. Growth, ruminal and metabolic parameters and feeding behavior of Nellore cattle with different residual feed intake phenotypes. Livest. Sci. 2021, 244, 104393. [CrossRef]

3. Koch, R.M.; Swiger, L.A.; Chambers, D.; Gregory, K.E. Efficiency of feed use in beef cattle. J. Anim. Sci. 1963, 22, 486-494. [CrossRef]

4. Berry, D.P.; Crowley, J.J. Residual intake and body weight gain: A new measure of efficiency in growing cattle. J. Anim. Sci. 2012, 90, 109-115. [CrossRef]

5. Elolimy, A.; Alharthi, A.; Zeineldin, M.; Parys, C.; Loor, J.J. Residual feed intake divergence during the preweaning period is associated with unique hindgut microbiome and metabolome profiles in neonatal Holstein heifer calves. J. Anim. Sci. Biotechnol. 2020, 11, 13. [CrossRef]

6. VandeHaar, M.J.; Armentano, L.E.; Weigel, K.; Spurlock, D.M.; Tempelman, R.J.; Veerkamp, R. Harnessing the genetics of the modern dairy cow to continue improvements in feed efficiency. J. Dairy Sci. 2016, 99, 4941-4954. [CrossRef]

7. Herd, R.M.; Oddy, V.H.; Richardson, E.C. Biological basis for variation in residual feed intake in beef cattle. 1. Review of potential mechanisms. Aust. J. Exp. Agric. 2004, 44, 423-430. [CrossRef]

8. Nkrumah, J.D.; Basarab, J.A.; Wang, Z.; Li, C.; Price, M.A.; Okine, E.K.; Crews, D.H., Jr.; Moore, S.S. Genetic and phenotypic relationships of feed and measures of efficiency with growth and carcass merit of beef cattle. J. Anim. Sci. 2007, 85, 2711-2720. [CrossRef]

9. Kelly, A.K.; McGee, M.; Crews, D.H., Jr.; Fahey, A.G.; Wylie, A.R.; Kenny, D.A. Effect of divergence in residual feed intake on feeding behavior, blood metabolic variables, and body composition traits in growing beef heifers. J. Anim. Sci. 2010, 88, 109-123. [CrossRef]

10. Montanholi, Y.R.; Swanson, K.C.; Palme, R.; Schenkel, F.S.; McBride, B.W.; Lu, D.; Miller, S.P. Assessing feed efficiency in beef steers trough feeding behavior, infrared thermography and glucocorticoids. Animal 2010, 4, 692-701. [CrossRef]

11. Leão, J.M.; Coelho, S.G.; Machado, F.S.; Azevedo, R.A.; Lima, J.A.M.; Carneiro, J.C.; Lage, C.F.A.; Ferreira, A.L.; Pereira, L.G.R.; Tomich, T.R.; et al. Phenotypically divergent classification of preweaned heifer calves for feed efficiency indexes and their correlations with heat production and thermography. J. Dairy Sci. 2018, 101, 1-9. [CrossRef] [PubMed]

12. AOAC. Official Methods of Analysis, 21st ed.; Association of Official Analytic Chemists-AOAC: Gaithersburg, MD, USA, 2019.

13. Van Soest, P.J.; Robertson, J.B.; Lewis, B.A. Methods for dietary fiber and non-starch polysaccharides in relation to animal nutrition. J. Dairy Sci. 1991, 74, 3583-3597. [CrossRef]

14. NRC. Nutrient Requirements of Dairy Cattle, 7th ed.; National Research Council-NRC: Washington, DC, USA, 2001.

15. Oliveira, B.R., Jr.; Ribas, M.N.; Machado, F.S.; Lima, J.A.M.; Cavalcanti, L.F.L.; Chizzotti, M.L.; Coelho, S.G. Validation of a system for monitoring individual feeding and drinking behavior and intake in young calves. Animal 2018, 12, 634-639. [CrossRef] [PubMed]

16. INCT-CA. Methods for Food Analysis; INCT: Viçosa, Brazil, 2012; Volume 14, pp. 199-204.

17. Lage, C.F.A.; Coelho, S.G.; Neto, H.C.D.; Malacco, V.M.R.; Rodrigues, J.P.C.; Sacramento, J.P.; Teixeira, V.A.; Machado, F.S.; Pereira, L.G.R.; Tomich, T.R.; et al. Relationship between feed efficiency indexes and performance, body measurements, digestibility, energy partitioning, and nitrogen partitioning in pre-weaned dairy heifers. PLOS ONE 2020, 15, e0236118. [CrossRef]

18. Basarab, J.A.; Price, M.A.; Aalhus, J.L.; Okine, E.K.; Snelling, W.M.; Lyle, K.L. Residual feed intake and body composition in young growing cattle. Can. J. Anim. Sci. 2003, 83, 189-204. [CrossRef]

19. McDonnell, R.P.; Hart, K.J.; Boland, T.M.; Kelly, A.K.; McGee, M.; Kenny, D.A. Effect of divergence in phenotypic residual feed intake on methane emissions, ruminal fermentation, and apparent whole-tract digestibility of beef heifers across three contrasting diets. J. Anim. Sci. 2016, 94, 1179-1193. [CrossRef] [PubMed]

20. Beede, D.K. Water nutrition and quality for dairy cattle. In Proceedings of the Western Large Herd Management Conference, Las Vegas, NV, USA, 22-24 April 1993; pp. 193-205.

21. Wickramasinghe, H.K.J.P.; Kramer, A.J.; Appuhamy, J.A.D.R.N. Drinking water intake of newborn dairy calves and its effects on feed intake, growth performance, health status, and nutrient digestibility. J. Dairy Sci. 2019, 102, 377-387. [CrossRef]

22. Beede, D.K. The most essential nutrient: Water. In Proceedings of the 7th Western Dairy Management Conference, Reno, NV, USA, 9-11 March 2005; pp. 13-32. 
23. Nkrumah, J.D.; Okine, E.K.; Mathison, G.W.; Schmid, K.; Li, C.; Basarab, J.A.; Price, M.A.; Wang, Z.; Moore, S.S. Relationship of feedlot feed efficiency, performance, and feeding behavior with metabolic rate, methane production, and energy partitioning in beef cattle. J. Anim. Sci. 2006, 84, 145-153. [CrossRef]

24. Green, T.C.; Jago, J.G.; Macdonald, K.A.; Waghorn, G.C. Relationship between residual feed intake, average daily gain, and feed behavior in growing dairy heifers. J. Dairy Sci. 2013, 96, 3098-3107. [CrossRef]

25. Berry, D.P.; Crowley, J.J. Cell Biology Symposium: Genetics of feed efficiency in dairy and beef cattle1. J. Anim. Sci. 2013, 91, 1594-1613. [CrossRef] [PubMed]

26. Guan, L.L.; Nkrumah, J.D.; Basarab, J.A.; Moore, S.S. Linkage of microbial ecology to phenotype: Correlation of rumen microbial ecology to cattle's feed efficiency. Microbol. Lett. 2008, 288, 85-91. [CrossRef] [PubMed]

27. Lam, S.; Munro, J.C.; Zhou, M.; Guan, L.L.; Schenkel, F.S.; Steele, M.A.; Miller, S.P.; Montanholi, Y.R. Associations of rumen parameters with feed efficiency and sampling routine in beef cattle. Animal 2018, 13, 1442-1450. [CrossRef] [PubMed]

28. Elolimy, A.A.; Arroyo, J.M.; Batistel, F.; Iakiviak, M.A.; Loor, J.J. Association of residual feed intake with abundance of ruminal bacteria and biopolymer hydrolyzing enzyme activities during the peripartal period and early lactation in Holstein dairy cows. J. Anim. Sci. Biotechnol. 2018, 9, 43. [CrossRef] [PubMed]

29. Silva, D.C.; Ribeiro, L.G.P.; Lima, J.A.M.; Machado, F.S.; Ferreira, A.L.; Tomich, T.R.; Coelho, S.G.; Maurício, R.M.; Campos, M.M. Grouping crossbred Holstein $x$ Gyr heifers according to different feed efficiency indexes and its effects on energy and nitrogen partitioning, blood metabolic variables and gas exchanges. PLoS ONE 2020, 15, e0238419. [CrossRef] [PubMed]

30. Kariza, B.K.; Thompson, J.; Wang, Z.; Li, C.; Montanholi, Y.R.; Miller, S.P.; Moore, S.S.; Plastow, G.S. Plasma metabolites associated with residual feed intake and other productivity performance traits in beef cattle. Livest. Sci. 2014, 165, 200-211. [CrossRef]

31. Moore, K.L.; Johnston, D.J.; Graser, H.U.; Herd, R. Genetic and phenotypic relationships between insulin-like growth factor-I (IGF-I) and net feed intake, fat, and growth traits in Angus beef cattle. Aust. J. Res. 2005, 56, 211-218. [CrossRef]

32. Brown, E.G.; Carstens, G.E.; Fox, J.T.; Curley, K.O., Jr.; Bryan, T.M.; Slay, L.J. Physiological Indicators of Performance and Feed Efficiency Traits in Growing Steers and Bulls; Beef Cattle Research: Collegue Station, TX, USA, 2004; pp. 163-166.

33. DiGiacomo, K.; Marett, L.C.; Wales, W.J.; Hayes, B.J.; Dunshea, F.R.; Leury, B.J. Thermoregulatory differences in lactating dairy cattle classed as efficient or inefficient based on residual feed intake. Anim. Prod. Sci. 2014, 54, 1877-1881. [CrossRef]

34. Martello, L.S.; Silva, S.L.; Gomes, R.C.; Corte, R.R.P.S.; Leme, P.R. Infrared thermography as a tool to evaluate body surface temperature and its relationship with feed efficiency in Bos indicus cattle in tropical conditions. Int. J. Biometeorol. 2016, 60, 173-181. [CrossRef]

35. Thompson, S.; Schaefer, A.L.; Crow, G.H.; Basarab, J.; Colyn, J.; Ominski, K. Relationship between residual feed intake and radiated heat loss using infrared thermography in young bulls. J. Therm. Biol. 2018, 78, 304-311. [CrossRef] 